\title{
Physicochemical properties of oci fish joruk (Rastrelliger kanagurta) and the antioxidant activity of joruk hydrolysate
}

\author{
${ }^{1}$ Anggrahini, S., ${ }^{1}$ Setyaningsih, W., ${ }^{1}$ Ningrum, A., ${ }^{2}$ Anto. and ${ }^{3}$ Agustiari, N.M. \\ ${ }^{1}$ Department of Food and Agricultural Product Technology, Faculty of Agricultural Technology, \\ Universitas Gadjah Mada, Jl. Flora No. 1, Bulaksumur, 55281 Yogyakarta,Indonesia \\ ${ }^{2}$ Ichsan Gorontalo University, Jl. Drs Achmad Nadjamuddin, Biyawao, Kota Selatan, Dulalowo Tim., Kota \\ Tengah, Kota Gorontalo, Gorontalo 96138 \\ ${ }^{3}$ Alumnus of Pascasarjana, Gadjah Mada University, Department of Food and Agricultural Product \\ Technology, Faculty of Agricultural Technology, Universitas Gadjah Mada, Jl. Flora No. 1, Bulaksumur, \\ 55281
}

\begin{abstract}
Article history:
Received: 13 October 2019

Received in revised form: 18

December 2019

Accepted: 20 December 2019

Available Online: 28 January 2020
\end{abstract}

Keywords:

Joruk,

Oci fish,

Fermentation,

Hydrolysis enzymes,

Hydrolysate

DOI:

https://doi.org/10.26656/fr.2017.4(3).336

\begin{abstract}
Joruk is a traditional fishery product made by spontaneous fermentation process using lactic acid bacteria by salting method, followed by fermentation process. Hydrolysis of proteins with the pepsin and a combination of pepsin and trypsin enzymes by in vitro can produce bioactive peptides. The aims of this study were to investigate the change of soluble protein and lactic acid content in oci fish joruk (Rastrelliger kanagurta) and to determine the influence of the enzyme hydrolysis on the antioxidant activity of joruk. The raw material used in this highest study was the oci fish obtained from Gorontalo, Indonesia. The produced joruk was added with the concentration of palm sugar 10\%, 20\% and 30\% then fermented for 8 days, 10 days and 12 days. Protein hydrolysis using the pepsin enzyme and a combination of pepsin and trypsin enzyme. The results showed that the addition of palm sugar and fermentation time can reduce soluble protein and increase the lactic acid content. The highest antioxidant activity was found in joruk hydrolysate that hydrolyzed by pepsin enzyme with the addition of $30 \%$ palm sugar and 12 days fermentation, with a value of $5.28 \%$.
\end{abstract}

\section{Introduction}

Oci fish (Rastrelliger kanagurta) is a fish found in Gorontalo, Gorontalo Province, Indonesia and was one of the leading fisheries commodities. Oci fish is the fourth highest captured fishery commodity after snapper, tuna and shrimp. Oci fish has an economic value, and its availability is abundant and high nutrient content. On the other hand, it is a perishable food, so good handling is needed to maintain the freshness of the fish and further processing is needed to extend its shelf life (Kusumanto, 2011; Koesoemawardani et al., 2016). One traditional method for extending the period of fish storage is by using fermentation (Hadiwiyoto, 1993; Je et al., 2005; Jung et al., 2006; Itou et al., 2007; Kleekayai et al., 2015).

Traditional fermentation in recent times has been investigated, mainly driven by its health benefits (Ohsima and Giri, 2014). Foods that were produced by the fermentation processes were claimed to prevent or cure various diseases. Protein degradation during fish fermentation and other marine products release amino acids and bioactive peptides which act as antioxidants (Peralta et al., 2008; Binsan et al., 2008; Faithong et al., 2010; Klomklao et al., 2010; Silvestre et al., 2013; Sheriff et al., 2014; Klukayai et al., 2015). One of the traditional fermented products made from oci fish was bekasam which was usually produced by adding cooked rice as a source of carbohydrates into the fish (Mukti et al., 2019). But in the Ogan Komering Ulu Timur District, South Sumatra, Indonesia there were fermented fish products that resemble the bekasam, namely joruk (Syarief and Halid, 1993; Wenno et al., 2016). Joruk is produced not only by adding cooked rice but also palm sugar. The addition of palm sugar serves as a source of carbohydrates and covers up the unpleasant aroma that typical of fermented fish which was less preferred.

Based on the research of Nuraini et al. (2014) and Hadiwiyoto (1993), it was known that the addition of cooked rice and palm sugar can reduce $\mathrm{pH}$ and increase the number of lactic acid bacteria. Based on the research of Koesoemawardani et al. (2016), it was known that the 
addition of $20 \%$ of palm sugar produced joruk with a typical aroma of fermented fish, the addition of $25 \%$ of palm sugar produced a joruk with a slight aroma of palm sugar and the addition of $50 \%$ palm sugar produced a slimy joruk.

Fermentation of joruk is categorized as lactic acid fermentation which used lactic acid bacteria producing proteolytic enzymes that will degrade fish proteins into bioactive peptides (Jung et al., 2006; Kim and Wijesekara, 2010; Wu et al., 2015). Bioactive peptides can be produced through acid or base hydrolysis, enzymatic hydrolysis, and microbial fermentation (Haque and Chand , 2008; Nalinanon et al., 2011; He et al., 2012; Rai et al., 2017; Noman et al., 2018). Protein hydrolysis using enzymes was an efficient way because it can produce protein hydrolyzates with minimal amino acid damage and expected to increase amino acids with the addition of carbon (Lahl and Braun, 1994; Kin and Wijesekara, 2010; Lee et al., 2010; Lee and Hur, 2017).

Research on the bioactive peptides of ACE-I from hydrolyzates of fermented marine products has been widely carried out, but not many have discussed the potential of oci fish joruk hydrolyzates with the addition of palm sugar followed by hydrolysis with the pepsin enzyme and a combination of pepsin and trypsin. The aims of this study were to determine the effect of differences in the concentration of palm sugar, the length of fermentation time and hydrolysis of enzymes against the activity of antioxidant activity of oci fish joruk hydrolyzates and the change of $\mathrm{pH}$ and lactic acid content during fermentation.

\section{Materials and methods}

\subsection{Materials}

Oci fish was obtained from fish suppliers in Gorontalo area, Gorontalo Province, Indonesia. Pepsin enzyme, trypsin enzyme, ACE enzyme, N-Hippuryl-HisLeu hydrate, hepes sodium salt, DPPH (2 2-diphenyl-1picrylhydrazyl), sodium chloride, acetic acid, 37\% hydrochloric acid, methanol, sodium hydroxide, sodium carbonate, potassium sodium tartrate tetrahydrate, copper (II) sulfate pentahydrate, Folin-Ciocalteu's phenol reagent, bovine serum albumin, trichloroacetic acid, distilled water and sterilized water for injections were purchased from Sigma Aldrich.

\subsection{Preparation of oci fish joruk}

The process of making oci fish joruk was referred to Wikandari and Yuanita (2011) and Nuraini et al. (2014) with modifications. Fresh oci fish was prepared (head, viscera, scales, and tails removed), cut into three pieces and washed with clean water. The fish was then weighed $100 \mathrm{~g}$, greased with $25 \%(\mathrm{w} / \mathrm{w})$ salt and put in a tightly closed glass jar. The jar was stored in a room that was not exposed to sunlight for 3 days. The fish was drained to remove the water that came out during the salting process. Then, $3.5 \%$ salt, $10 \%$ cooked rice and palm sugar of different concentrations $(10 \%, 20 \%$, and $30 \%)$ were added and proceeded with the fermentation in tightly closed glass jar for 8,10 , and 12 days.

\subsection{Preparation of oci fish joruk extract}

The process of making joruk extract refers to the method by Wikandari and Yuanita (2016) with modifications. A total of $50 \mathrm{~g}$ of oci fish joruk was added with $100 \mathrm{~mL}$ of distilled water and blended until homogeneous. The solution was then centrifuged for 40 mins at $3.000 \mathrm{x} g$. The supernatant was separated and set aside (supernatant 1), while the formed precipitate was added with $50 \mathrm{~mL}$ distilled water then centrifuged for 20 mins at 3,000 $\mathrm{x} g$ (supernatant 2). The supernatant 1 was mixed with supernatant 2 and then filtered with filter paper.

\subsection{Hydrolysis of oci fish joruk extract}

The hydrolysis process of oci fish joruk extract with the enzyme pepsin and trypsin refers to method by Ismanto (2014) with modifications. A total of $20 \mathrm{~mL}$ extract is expected to have a protein content of $5 \mathrm{mg} / \mathrm{mL}$. The $\mathrm{pH}$ of the extract was adjusted to $\mathrm{pH} 2$ by adding 1 $\mathrm{N} \mathrm{HCl}$, then hydrolyzed by the pepsin enzyme with a ratio of $1: 100(0.01 \mathrm{~g}$ of pepsin enzyme dissolved in 1 $\mathrm{mL}$ water for injections) and incubated in a shaking water bath at $37^{\circ} \mathrm{C}$ for $2 \mathrm{hrs}$. The $\mathrm{pH}$ was then adjusted to $\mathrm{pH} 7$ by adding $1 \mathrm{M} \mathrm{NaOH}$. Next, trypsin enzyme was added with a ratio of 1:100 (1 mg trypsin enzyme dissolved in $1 \mathrm{mM} \mathrm{HCl}$ ) and incubated at shaking water bath at $37^{\circ} \mathrm{C}$ for $2 \mathrm{hrs}$. The reaction was stopped by heating at $95^{\circ} \mathrm{C}$ for 10 mins and then cooled in ice water (Cushman and Cheung, 1971).

\subsection{Analysis of antioxidant activity}

Analysis of free radical inhibition activity on DPPH substrate was carried out by taking $1 \mathrm{~mL}$ of sample (the result of dilution of $1 \mathrm{~mL}$ of hydrolysate sample in $5 \mathrm{~mL}$ of methanol) and added with $3 \mathrm{~mL}$ of DPPH $0.1 \mathrm{mM}$ solution in methanol. The mixture was vortexed and incubated for 30 mins in a dark room. Then, the absorbance was measured at a $517 \mathrm{~nm}$ using a spectrophotometer. Vitamin C (20 ppm) was used as control. The percentage of inhibition of antioxidants is calculated by the formula:

$$
\text { antioxidant inhibition }(\%)=\frac{A c-A s}{A c} \times 100 \%
$$


Where As is the sample absorbance and Ac is the blank absorbance which is the absorbance of solvent sample added with DPPH.

\subsection{Determination of total organic acid}

A total of $10 \mathrm{~mL}$ of hydrolysate samples of were added with three drops of phenolphthalein (PP) indicator and then titrated with $0.1 \mathrm{~N}$ of $\mathrm{NaOH}$. Titration was conducted in triplicate. The titration was terminated when the pink color appeared. Total organic acid was measured as the percent of lactic acid according to the equation below (Wikandari and Yuanita, 2011)

$$
\% \text { lactic acid }=\frac{\mathrm{M} 1 \mathrm{NaOH} \times \mathrm{N} \mathrm{NaOH} \times \frac{1}{10} \times 90}{\mathrm{~mL} \text { samples }}
$$

\subsection{Soluble protein analysis}

Soluble protein was determined according to the Lowry method (Lowry et al., 1951). A sample of $10 \mathrm{~mL}$ was added with $5 \mathrm{~mL}$ of trichloroacetic acid and centrifuged at $5000 \mathrm{x} g$ for 20 mins. The supernatant of $0.1 \mathrm{~mL}$ was added with $3.9 \mathrm{~mL}$ of distilled water and 5.5 $\mathrm{mL}$ of Lowry reagent. The mixture was left undisturbed for 10 mins, then $0.5 \mathrm{~mL}$ of Folin reagent was added and incubated for $30 \mathrm{~min}$ at room temperature. The standard protein used was Bovine Serum albumin (BSA). Soluble protein content was measured at $600 \mathrm{~nm}$. The determination was done in triplicates (Wikandari and Yuanita, 2011).

\subsection{Statistical analysis}

This study was carried out by an experimental method. The experimental design used a Randomized Block Design, factorial $3 \times 3$. ANOVA was used to statistically analyse the data at $95 \%$ confidence level. Independent sample t-test was used to analyse the hydrolysis process data of pepsin and trypsin enzyme at 95\% confidence level. Data was analyzed using the IBM SPSS Statistics version 23.

\section{Results and discussion}

\subsection{Effect of palm sugar concentration and fermentation} time on the soluble protein content of oci fish joruk

Soluble protein is a protein in food that can be dissolved into a solution. The solubility of a protein is related to its structure (Hutabarat, 2018). The results on soluble protein content analysis can be seen in Table 1 and Table 2. An increase in the soluble protein content of oci fish joruk after fermentation occurred due to protein degradation by lactic acid bacteria that produced shortchain peptides that have high solubility in water.

Statistical analysis showed that palm sugar concentration caused no significant increase in the soluble protein content of oci fish joruk. Choong et al. (2016) stated that palm sugar contains $9.31 \%$ of reducing sugar so the higher the palm sugar concentration, the higher the reducing sugar in oci fish joruk. Toe et al. (2019) in his research on the proteolytic activity of lactic acid bacteria said that the addition of reducing sugar did not have a significant effect on the proteolytic activity of lactic acid bacteria, one of which is Lactobacillus plantarum, a lactic acid bacteria predominantly found in fish. This caused no significant increase in the soluble protein content because reducing sugar does not give any significant influence on the proteolytic activity of lactic acid bacteria.

Table 1. Effect of interaction of the main factors on soluble protein content of oci fish joruk

\begin{tabular}{cccc}
\hline Fermentation & \multicolumn{3}{c}{ Palm sugar concentration $(\% \mathrm{w} / \mathrm{w})$} \\
\cline { 2 - 4 } Time (day) & 10 & 20 & 30 \\
\hline 8 & $26.26 \pm 2.94$ & $26.63 \pm 0.93$ & $27.05 \pm 0.87$ \\
10 & $28.38 \pm 0.26$ & $28.53 \pm 0.03$ & $28.82 \pm 0.49$ \\
12 & $29.03 \pm 0.75$ & $29.18 \pm 0.52$ & $29.29 \pm 0.51$ \\
\hline
\end{tabular}

Table 2. Effects of main factors on soluble protein content of oci fish joruk

\begin{tabular}{lccc}
\hline Soluble Protein $(\%)$ & -1 & 0 & 1 \\
\hline Palm sugar & $27.89 \pm 1.97$ & $28.11 \pm 1.26$ & $28.52 \pm 0.99$ \\
\hline Fermentation time & $26.78 \pm 1.69^{\mathrm{b}}$ & $28.58 \pm 0.34^{\mathrm{a}}$ & $29.17 \pm 0.54^{\mathrm{a}}$ \\
\hline $\begin{array}{l}\text { Different notation on numbers showed a significant difference } \\
(p<0.05)\end{array}$ & & &
\end{tabular}

Fermentation time caused a significant increase in the soluble protein content of oci fish joruk, as shown by the statistical analysis. These results indicate that the longer the fermentation time, the higher the soluble protein content. The increase in soluble protein content showed that there was fish protein degradation happening during the fermentation. Protein degradation results in an increase in peptide contents and free amino acids which have high solubility in water, observed in many fermentation products including teri fish rusip (Yuliana, 2007).

No interactions were gathered between two main factors on the soluble protein content because the effect of palm sugar concentration does not depend on the fermentation time and vice versa. Reiteration did not affect the soluble protein content of oci fish joruk significantly. This shows that the production of oci fish joruk and the soluble protein content analysis can be replicated.

3.2 Effect of palm sugar concentration and fermentation time to total lactic acid of oci fish joruk

Total lactic acid is the amount of lactic acid 
produced during fermentation. The results on total lactic acid analysis can be seen in Table 3 and Table 4. A preliminary analysis had been carried out to determine the total lactic acid of fresh oci fish and $4.68 \%$ was obtained as the result. An increase in total lactic acid of oci fish after fermentation occurred because conversion of sugar in the form of carbohydrate and palm sugar into lactic acid by lactic acid bacteria happened.

Table 3. Effect of interaction of the main factors on total lactic acid of oci fish joruk

\begin{tabular}{cccc}
\hline \multirow{2}{*}{$\begin{array}{c}\text { Fermentation } \\
\text { Time (day) }\end{array}$} & \multicolumn{3}{c}{ Palm sugar concentration $(\% \mathrm{w} / \mathrm{w})$} \\
\cline { 2 - 4 } & 10 & 20 & 30 \\
\hline 8 & $17.21 \pm 0.21$ & $17.54 \pm 0.09$ & $17.67 \pm 0.31$ \\
10 & $17.42 \pm 0.33$ & $17.62 \pm 0.13$ & $17.71 \pm 0.06$ \\
12 & $17.49 \pm 0.07$ & $17.64 \pm 0.04$ & $17.73 \pm 0.06$ \\
\hline
\end{tabular}

Table 4. Effects of main factors on total lactic acid of oci fish joruk

\begin{tabular}{lccc}
\hline Total Lactic Acid & -1 & 0 & 1 \\
\hline Palm sugar & $17.37 \pm 0.24^{\mathrm{b}}$ & $17.60 \pm 0.09^{\mathrm{a}}$ & $17.70 \pm 0.16^{\mathrm{a}}$ \\
\hline Fermentation time & $17.47 \pm 0.28$ & $17, .8 \pm 0.22$ & $17.64 \pm 0.04$ \\
\hline $\begin{array}{l}\text { Different notation on numbers showed a significant difference } \\
(p<0.05)\end{array}$
\end{tabular}

Statistical analysis showed that palm sugar concentration gave a significant increase to the total lactic acid of oci fish joruk. The total lactic acid in $10 \%$ of palm sugar concentration was significantly different from $20 \%$ and $30 \%$ palm sugar concentration. The higher the palm sugar concentration, the higher the total lactic acid of oci fish joruk. It is due to the increase of carbon sources that can be converted into lactic acid so that the conversion of organic acids such as lactic acid is also increasing (Bartoldi et al., 2002).

Nuraini et al. (2014) stated that the total lactic acid in tilapia fish with the addition of 3\% brown sugar was higher compared to the one without the addition of brown sugar. Koesoemawardani et al. (2016) in the study of wader fish joruk stated that the total lactic acid of wader fish joruk with the addition of $10 \%$ palm sugar was lower than the wader fish joruk with the addition of $20 \%$ palm sugar. The results are supported by Wardhani (2019) stating that the concentration of palm sugar caused a significant decrease in the $\mathrm{pH}$ of oci fish joruk. The decrease in $\mathrm{pH}$ indicated an increase in total lactic acid produced during the fermentation of oci fish joruk.

Fermentation time did not cause a significant effect on the total lactic acid of oci fish joruk. It was caused by the amount of lactic acid that will increase insignificantly after 60 hours of fermentation time, stated by Kim et al. (2013). Zhang et al. (2007) stated in his research on the effect of fermentation time on lactic acid that lactic acid bacteria would produce the optimum amount of lactic acid at a fermentation time of 120 hours before showing no significant increase.

No interactions were gathered between two main factors on the total lactic acid because the effect of palm sugar concentration does not depend on the fermentation time and vice versa. Reiteration did not affect the total lactic acid of oci fish joruk significantly. This shows that the production of oci fish joruk and total lactic acid analysis can be replicated.

\subsection{Antioxidant activity}

The antioxidant activity of oci fish joruk hydrolysates hydrolyzed by the pepsin enzyme (A) and a combination of pepsin and trypsin enzymes (B) with the addition of different concentrations of palm sugar during the fermentation process is presented in Figure 1.
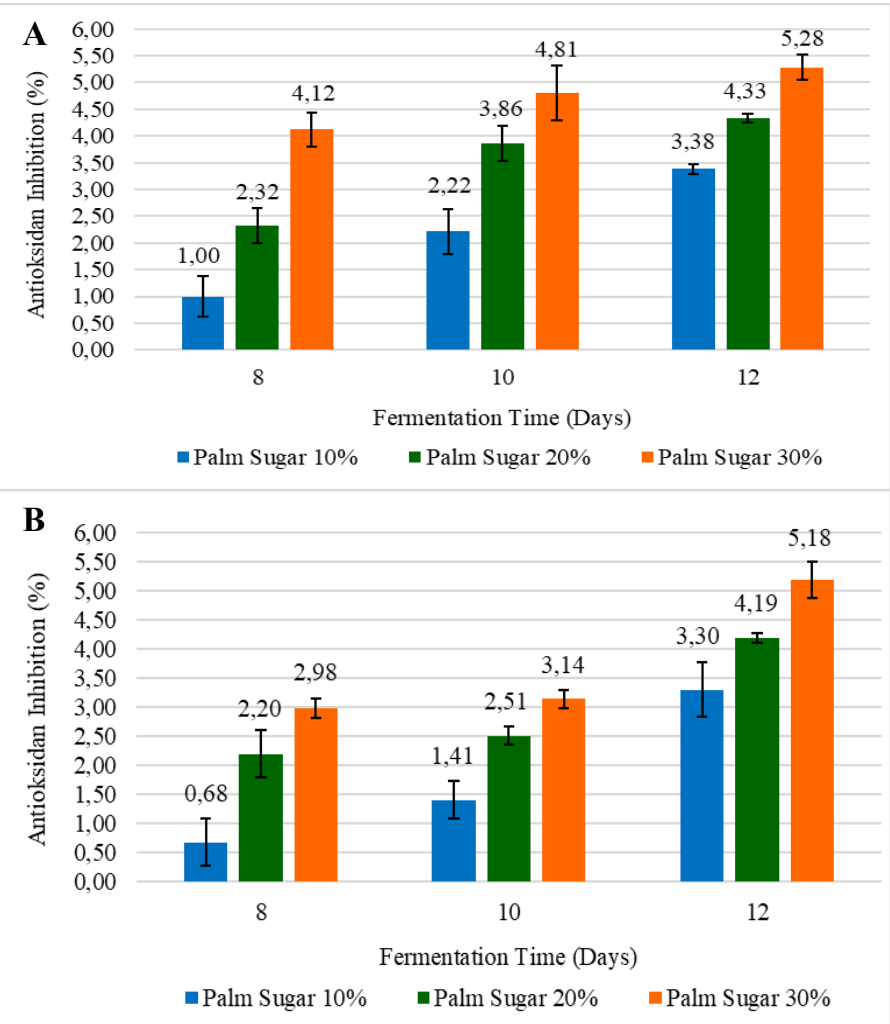

Figure 1. Diagram of antioxidant activity of oci fish joruk hydrolyzed by the pepsin enzyme (A) and oci fish joruk hydrolyzed by the pepsin and trypsin enzymes (B) with the addition of different concentrations of palm sugar during the fermentation process

The antioxidant activity of oci fish joruk hydrolysate hydrolyzed by pepsin enzyme was $1.00 \%$ up to $5.28 \%$. The highest value was found in oci fish joruk hydrolysate samples with the addition of $30 \%$ palm sugar at 12 th day fermentation $(5.28 \%)$. The value of the antioxidant activity of oci fish joruk hydrolysate which was hydrolyzed by pepsin and trypsin enzymes was $0.68 \%$ up to $5.18 \%$. The highest value was found in 
hydrolysate samples with the addition of $30 \%$ palm sugar on the 12th day fermentation $(5.18 \%)$.

The results of antioxidant activity were inversely proportional to the results of dissolved protein values, degree of hydrolysis and ACE-I activity. This was presumably because the bioactive peptides that provide high antioxidant activity were peptide chains with nonaromatic amino acid residues while the pepsin enzyme in hydrolyzing proteins tends to bond in carboxyl terminals with aromatic amino acid residues, so the peptides hydrolyzed by the pepsin enzyme were sequences of ACE-I peptide rather than antioxidants. Mendis et al. (2005) added that the presence of non-aromatic amino acids such as proline, alanine, valine and leucine contribute to higher antioxidant activity. Phenylalanine and leucine residues at terminals $\mathrm{N}$ and $\mathrm{C}$ peptides contribute to antioxidant activity. The value of antioxidant activity in this study approaches the results of research conducted by Borawska et al. (2016), carp which was hydrolyzed by pepsin enzyme have antioxidant activity value of $2.3 \%$ in sarcoplasmic protein and $6.0 \%$ in myofibril protein.

The value of antioxidant activity decreased in the treatment of adding palm sugar with low concentrations $(10 \%$ and $20 \%)$ and showed significant differences (P $<0.05)$. The 8 th and 10 th days of fermentation showed a smaller antioxidant activity compared to 12th day fermentation even though it was not significantly different $(\mathrm{P}>0.05)$. The results of antioxidant activity on oci fish joruk hydrolysate samples that hydrolyzed with pepsin and trypsin enzymes have the same tendency as the results of the samples which were hydrolyzed with pepsin enzyme. This was presumably because the specificity of the work of the pepsin and trypsin enzymes in hydrolyzing peptide bonds were not produced peptides which sequence with antioxidant peptides so that if the two enzymes were combined, the antioxidant activity value will be small.

According to Vignesh et al. (2011), the antioxidant activity of protein hydrolysates depends on the levels and composition of amino acids and peptides in the sample. In addition, Lassoued et al. (2015) states that antioxidant activity is related to amino acid constituents, sequence and hydrophobicity. Most of the antioxidant peptides are identified to have short peptide chains (5-16 amino acids) and contain valine and leucine hydrophobic amino acids in N-terminals. Tyrosine contributes substantially to the inhibition of free radicals because its phenolic chain acts as a strong electron donor, allowing it to stop the chain of radical reactions. Hydrophobic amino acids leucine and proline play an important role in inhibiting radicals via hydrogen atoms or transferring electrons and inhibiting oxygen reactive (Fujita et al. (2001).

\section{Conclusion}

The conclusion that can be drawn from this study was the addition of palm sugar and fermentation time can reduce the soluble protein and increase the lactic acid content. The highest antioxidant activity with a value of $5.28 \%$ was found in the joruk hydrolysate which was hydrolyzed by pepsin enzyme with the addition of $30 \%$ palm sugar and during 12 days fermentation.

\section{Conflict of Interest}

The authors declare no conflict of interest.

\section{Acknowledgment}

Authors thankful to Kemenristek DIKTI Indonesia by PDUPT Program for supporting this research. The authors wish to thank to Dr. Arlavinda Rezqita, Austrian Institute of Technology (AIT), Austria for careful reading of the manuscript and editorial help.

\section{References}

Binsan, W., Benjakul, S., Visessanguan, W., Roytrakul, S., Tanaka, M. and Kishimura, H. (2008). Antioxidative activity of Mungoong, an extract paste, from the cephalothorax of white shrimp (Litopenaeus vannamei). Food Chemistry, 106(1), 185-193.

j.foodchem.2007.05.065

Cushman, D.W. and Cheung, H.S. (1971). Spectrophotometric assay and properties of the angiotensin-converting enzyme of rabbit lung. Biochemical Pharmacology, 20(7), 1637-1648. https://doi.org/10.1016/0006-2952(71)90292-9

Faithong, N., Benjakul, S., Phatcharat, S. and Binsan, W. (2010). Chemical composition and antioxidative activity of Thai traditional fermented shrimp and krill products. Food Chemistry, 119(1), 133-140. https://doi.org/10.1016/j.foodchem.2009.06.056

Fujita, H., Yamagami, T. and Ohshima, K. (2001). Effects of an ace-inhibitory agent, katsuobushi oligopeptide, in the spontaneously hypertensive rat and in borderline and mildly hypertensive subjects. Nutrition Research, 21(8), 1149-1158. https:// doi.org/10.1016/S0271-5317(01)00333-5

Hadiwiyoto, S. (1993). Teknologi Hasil Perikanan. Jilid 1., p. 148. Yogyakarta: Penerbit Liberty. [In Bahasa Indonesia].

Haque, E. and Chand, R. (2008). Antihypertensive and antimicrobial bioactive peptides from milk proteins. European Journal of Food Research and 
Technology, 227(1), 7-15. https://doi.org/10.1007/ s00217-007-0689-6

He, R., Ma, H., Zhao, W., Qu, W., Zhao, J., Luo, L. and Zhu, W. (2012). Modeling the QSAR of ACEinhibitory peptides with ANN and its applied illustration. International Journal of Peptides, 2012, 1-9. https://doi.org/10.1155/2012/620609

Hutabarat, S.R. (2018). Pengaruh penambahan gula aren (Arengapinnata) terhadap mutu bekasam ikan nila (Oreochromis niloticus). Indonesia: Universitas Riau. Pekanbaru. [In Bahasa Indonesia].

Ismanto, A. (2014). Evaluasi proses hidrolisis enzimatis protein ranggah velvet rusa sambar (Rusa unicolor) sebagai tahap awal untuk menghasilkan peptida bioaktif. Retrieved from Prosiding Seminar Kimia website: http://jurnal.kimia.fmipa.unmul.ac.id/ index.php/prosiding/article/view/145. [In Bahasa Indonesia].

Itou, K., Nagahashi, R., Saitou, M. and Akahane, Y. (2007). Antihypertensive effect of narezushi, a fermented mackerel product, on spontaneously hypertensive rats. Fish Science, 73(6), 1344-1352.

Je, J.Y., Park, J.-Y., Jung, W.-K., Park, P.-J. and Kim, S. -K. (2005). Isolation of angiotensin I converting enzyme (ACE) inhibitor from fermented oyster sauce, Crassostrea gigas. Food Chemistry, 90(5), 809-814.

https://doi.org/10.1016/

j.foodchem.2004.05.028

Jung, W.K., Mendis, E., Je, J.-Y., Park, P.-Y., Son, B.W., Kim, H.C., Choi, Y.K. and Kim, S.-K. (2006). Angiotensin I-converting enzyme inhibitory peptide from yellowfin sole (Limanda aspera) frame protein and its antihypertensive effect in spontaneously hypertensive rats. Food Chemistry, 94(1), 26-32. https://doi.org/10.1016/j.foodchem.2004.09.048

Kim, S.K. and Wijesekara, I. (2010). Development and biological activities of marinederived bioactive peptides: A review. Journal of Functional Foods, 2(1), 1-9. https://doi.org/10.1016/ j.jff.2010.01.003

Kleekayai, T., Saetae, D., Wattanachaiyingyong, O., Tachibana, S.. Yasuda, M. and Suntornsuk, W. (2015). Characterization and in vitro biological activities of Thai traditional fermented shrimp pastes. Journal of Food Science and Technology, 52 (3), 1839-1848. https://doi.org/10.1007/s13197-014$1528-y$

Klomklao, S., Benjakul, S., Kishimura, H., Osako, K. and Tanaka, M. (2010). Effect of salts and polyethylene glycols on the partitioning and recovery of trypsin from hybrid catfish viscera in aqueous two-phase systems. Journal of Food
Biochemistry, doi.org/10.1111/j.1745-4514.2009.00311.x

https://

Koesoemawardani, D., Marniza, M., Rizal, S. and Sella, N. (2016). Penambahan konsentrasi gula aren pada joruk (produk ikan fermentasi). Prosiding Seminar Nasional Pengembangan Teknologi Pertanian Politeknik Negeri Lampung, 8 September 2016., p. 187-195. Retrieved from Prosiding Seminar Nasional Pengembangan Teknologi Pertanian website: https://jurnal.polinela.ac.id/index.php/ PROSIDING/article/view/477/344. [In Bahasa Indonesia].

Kusumanto, D. (2011). Tabel Komposisi Kimia Nira dan Gula Aren. http://kebunaren.blogspot.com/2011/02/ tabel-komposisi-kimia-nira-dan-gula.html (diakses pada tanggal 27 Juni 2019). [In Bahasa Indonesia].

Lahl, W.J. and Braun, S.D. (1994). Enzymatic production of protein hydrolysates for food use. Food Technology, 48(10), 68-71.

Lee, S.Y. and Hur, S.J. (2017). Antihypertensive peptides from animal products, marine organisms, and plants. Food Chemistry, 228, 506-517. https:// doi.org/10.1016/j.foodchem.2017.02.039

Lee, S.H., Qian, Z.I. and Kim, S.K. (2010). A novel angiotensin I converting enzyme inhibitory peptide from tuna frame protein hydrolysate and its antihypertensive effect in spontaneously hypertensive rats. Food Chemistry, 118(1), 96-102. https://doi.org/10.1016/j.foodchem.2009.04.086

Lowry, O.H., Rosebrough, N.J., Farr, A.I. and Randall, R.J. (1951). Protein measurement with the Folin phenol reagent. Journal of Biological Chemistry, 193, 265-275.

Mukti, K.S., Rohmawati, N. and Sulistiyani, S. (2019). Analisis kandungan karbohidrat, glukosa, dan uji daya terima pada nasi bakar, nasi panggang, dan nasi biasa. Jurnal Agroteknologi, 12(1), 90-99. https:// doi.org/10.19184/j-agt.v12i1.8333. [In Bahasa Indonesia].

Nalinanon, S., Benjakul, S., Kishimura, H. and Shahidi, F. (2011). Functionalities and antioxidant properties of protein hydrolysates from the muscle of ornate threadfin bream treated with pepsin from skipjack tuna. Food Chemistry, 124(4), 1354-1362. https://doi.org/10.1016/j.foodchem.2010.07.089

Noman, A., Xu, Y., AL-Bukhaiti, W.Q., Abeda, S.M., Alia, A.H., Ramadhana, A.H. and Xia, W. (2018). Influence of enzymatic hydrolysis conditions on the degree of hydrolysis and functional properties of protein hydrolysate obtained from Chinese sturgeon (Acipenser sinensis) by using papain enzyme. Process Biochemistry, 67, 19-28. https:// 
doi.org/10.1016/j.procbio.2018.01.009

Nuraini, A., Ibrahim, R. and Rianingsih, L. (2014). Pengaruh penambahan konsentrasi sumber karbohidrat dari nasi dan gula merah yang berbeda terhadap mutu bekasam ikan nila merah (Oreochromis niloticus). Jurnal Saintek Perikanan, 10(1), 19-25. [In Bahasa Indonesia].

Ohshima, T. and Giri, A. (2014). Fermented Foods: Traditional Fish Fermentation Technology and Recent Developments. In Batt, C.A. and Tortorello, M.L. (Eds.). Encyclopedia of Food Microbiology. $2^{\text {nd }}$ ed. USA: ScienceDirect. https://doi.org/10.1016/ B978-0-12-384730-0.00117-8

Peralta, E.M., Hatate, H., Kawabe, D., Kuwahara, R., Wakamatsu, S., Yuki, T. and Murata, H. (2008). Improving antioxidant activity and nutritional components of Philippine salt-fermented shrimp paste through prolonged fermentation. Food Chemistry, 111(1), 72-77. https://doi.org/10.1016/ j.foodchem.2008.03.042

Rai, A.K., Sanjukta, S. and Jeyaram, K. (2017). Production of angiotensin I converting enzyme inhibitory (ACE-I) peptides during milk fermentation and their role in reducing hypertension. Critical Review in Food Science and Nutrition, 57 (13), 2789-2800. https:// doi.org/10.1080/10408398.2015.1068736

Sheriff, S.A., Sundaram, B., Ramamoorthy, B. and Ponnusamy, P. (2014). Synthesis and in vitro antioxidant functions of protein hydrolysate from backbones of Rastrelliger kanagurta by proteolytic enzymes. Saudi Journal of Biological Science, 21(1), 19-26. https://doi.org/10.1016/j.sjbs.2013.04.009

Silvestre, J.S., Smadja, D.M. and Lévy, B.I. (2013). Postischemic Revascularization: From Cellular and Molecular Mechanisms to Clinical Applications. Physiological Reviews, 93(4), 1743-1802. https:// doi.org/10.1152/physrev.00006.2013

Syarief, S. and Halid, H. (1993). Teknologi Penyimpanan Pangan., p. 347. Jakarta, Indonesia: Penerbit Arcan. [In Bahasa Indonesia].

Wenno, M.R., Suprayitno, E., Aulanni'am, A. and Hardoko. (2016). Identification and molecular interaction mechanism angiotensin converting enzyme inhibitory peptide from bakasang (Fermented Skipjack Tuna (Katsuwonus pelamis)). International Journal of PharmTech Research, 9 (12), 591-598.

Wikandari, P.R. and Yuanita, L. (2016). Pengaruh degradasi enzim proteolitik terhadap aktivitas angiotensin converting enzyme inhibitor bekasam dengan Lactobacillus plantarum B1765. Journal of
Agritechnology, 36(2), 170-175. https:// doi.org/10.22146/agritech.12861. [In Bahasa Indonesia].

Wu, S., Feng, X., Lan, X., Xu, Y. and Liao. D. (2015). Purification and identification of Angiotensin-I Converting Enzyme (ACE) inhibitory peptide from lizard fish (Saurida elongata) hydrolysate. Journal of Functional Foods, 13, 295-299. https:// doi.org/10.1016/j.jff.2014.12.051 